DOI: $10.21802 / \operatorname{artm} .2021 .1 .17 .18$.

UDC 615.825:616.831

\title{
PHYSICAL THERAPY FOR PATIENTS AFTER STROKE
}

\author{
A.V. Homola, Ye.V. Prokopovych, Y.V. Antonova-Rafi \\ National Technical University of Ukraine "KPI" named after Igor Sikorsky, Department of \\ Biomedical Engineering, Kiev, Ukraine, \\ ORCID ID: 0000-0001-7431-1889, \\ ORCID ID: 0000-0002-7107-5021, \\ ORCID ID: 0000-0002-9518-4492, \\ e-mail:alhzgv@gmail.com
}

Abstract. Objectives: to summarize the data on the spread and complications of patients after stroke in Ukraine and in the world, the noted motor and cognitive impairments are the basis of disability; to prove the effectiveness of physical therapy methods for recovery of motor function of patients after a stroke. The strategy of solving the problem consists in reducing the limitations of daily living activities, increased mastering new skills and abilities. Patients are examined using modern tests and scales, which allow summarizing the examination results, and having a high level of reliability.

Purpose of the study: the dynamics of the functional motor state of patients after undergoing complex physical therapy. The effectiveness of the methods at the stage of restoration of motor abilities has been substantiated.

Methods. Every day at the MDK meeting, communication takes place in accordance with medical ethics and moral principles, the legal norms of the patient and his family. On the basis of the Kiev City Clinical Hospital № 6, the Department of Physical and Rehabilitation Medicine 34 patients were separated in the early recovery period with plegia of the upper limb and divided into two groups: the main and the control one. In the late period after a stroke with spasticity of the upper limb, 26 patients were also divided into two groups. Women age ranges from 35 to 83 years old; men - from 37 to 84 years old. The dynamics of the functional motor state of patients after undergoing complex physical therapy was investigated.

Research results. In Ukraine, there are many versions of physical therapy for patients after stroke in the acute and early period. The Ukrainian Stroke Association has created protocols for rehabilitation assistance. Some success has been achieved in the rehabilitation of patients in the acute period. Difficulties arise in the late period of physical therapy, namely, functional motor disorders. This negatively affects the social and everyday activity and the usual activities of patients. The consequences of a stroke are muscular disorders such as a complete absence of voluntary movements (plegia), accompanied by a painful syndrome, loss of balance, coordination during movement. Also, the growing spasticity that forms contractures, there are pain sensations and restrictions in everyday activities. Patients face the problem of muscle spasticity, which interferes with a full-fledged rehabilitation process, becomes an obstacle in the restoration of motor functions, leads to a loss of working capacity, self-care skills, and sharply reduces the quality of life. A physical therapist must own, know and use the methods and means of physical therapy. The use of the international classification of functioning influences the course of work of a multidisciplinary team, aimed at a direct and specific rehabilitation process for the qualitative and complex restoration of the patient's lost motor functions.

Conclusion. On the basis of the Kiev City Clinical Hospital № 6, Department of Physical and Rehabilitation Medicine, developed a complex program of physical therapy, for a group of patients after stroke. The multidisciplinary team does not divide life before and after a stroke, it tries, on the basis of evidence-based medicine, an integrated and individual approach to activate an independent life, help and restore the patient's lost functions, compensate and find a way out where others refuse.

Keywords: stroke, rehabilitation, physical therapy, multidisciplinary team, International classification of functioning.

Introduction. The problem of cerebral stroke is extremely urgent, due to the severe consequences and insufficient effectiveness of treatment. Globally, stroke leads to about $6-6,500,000$. Lethal outcomes, and in the structure of mortality is second only to coronary heart disease.

Stroke affects the loss of performance, movement and limitations in daily life. In 2017, the Stroke Alliance for Europe (SAFE), together with the European Stroke Organization (ESO), carried out a comprehensive review of the problem. According to their report "Burden of Stroke in Europe," strokes are expected to rise by $34 \%$ by 2035 due to an aging population.

In Ukraine, according to the Center for Public Health of the Ministry of Health of Ukraine, 100-110 thousand - strokes occur annually, 30-40\% of patients die in the first 30 days after a cerebral catastrophe, up to $50 \%$ - during the first year from the onset of the disease; $20-40 \%$ of patients who survived become dependent on outside help ( $12.5 \%$ of primary disability), only about $10 \%$ return to full life. According to the statistical indicators given in the profile unified clinical protocol of medical care, the 
incidence of ischemic stroke in Ukraine is 280-290 cases per 100 thousand of the population and exceeds the average in the developed countries of Europe (200 cases per 100 thousand of the population). According to the Ministry of Health, in $2015,96,319$ strokes were officially registered in Ukraine (274.1 cases per 100 thousand of the population), in 2016 - 97,805 (279.6 cases per 100 thousand of the population), in 2017 - 96978 (278.7 cases per 100 thousand population). As a result of cerebral stroke in Ukraine, 40-45 thousand people die annually (more than 87 deaths per 100 thousand population). In Europe, this figure is much lower - 37 - 47 cases per 100 thousand. In 2019, almost 97,000 strokes were registered in Ukraine. But experts say that the situation in Ukraine is even sadder, $20-30 \%$ of people with a stroke do not go to hospitals, so the statistics are not reliable [14].

Rationale for the study. The list of patient problems is constructed according to the International Classification of Functioning (ICF), adopted by WHO in May 2001, as an international standard for describing and measuring health and disability. The ICF provides a framework for organizing and maintaining records of functioning and disability, as well as qualifications and codes that are used throughout life and for all age groups. On the basis of ICF, long-term (weeks-months) are coordinated with the patient and his family, reaching the goal, changing in short-term (days-weeks) [6].
The main components of the MDK, setting goals in rehabilitation:

Identification of needs or problems $\rightarrow$ Setting long-term goals $\rightarrow$ Leading to short-term goals $\rightarrow$ Plan of action $\rightarrow$ Methods of examination in physical therapy or occupational therapy $\rightarrow$ Achievable goals and plan of action may change $\rightarrow$ Reevaluation $\rightarrow$ Final evaluation of the effectiveness of the intervention.

The goal requires an answer to the question: Who? - What? - How? - When?

The goals of physical therapy are considered in a SMART format, making it possible to achieve maximum results: family);

- S (specific) specific (wishes of the patient and

- M (measurable) measured in time;

- A (achievable) achievable;

- $\mathrm{R}$ (realistic) realistic;

- T (timed) are defined in time [3].

Physical therapy for stroke patients begins from the first day of stay in the rehabilitation department. According to clinical guidelines, a specialized rehabilitation department, in which the MDC is in full force. This allows us to help patients after a stroke with quality at all stages. The use of evidence-based medicine makes it possible to qualitatively perform rehabilitation without complications and disabilities $[1,10]$.

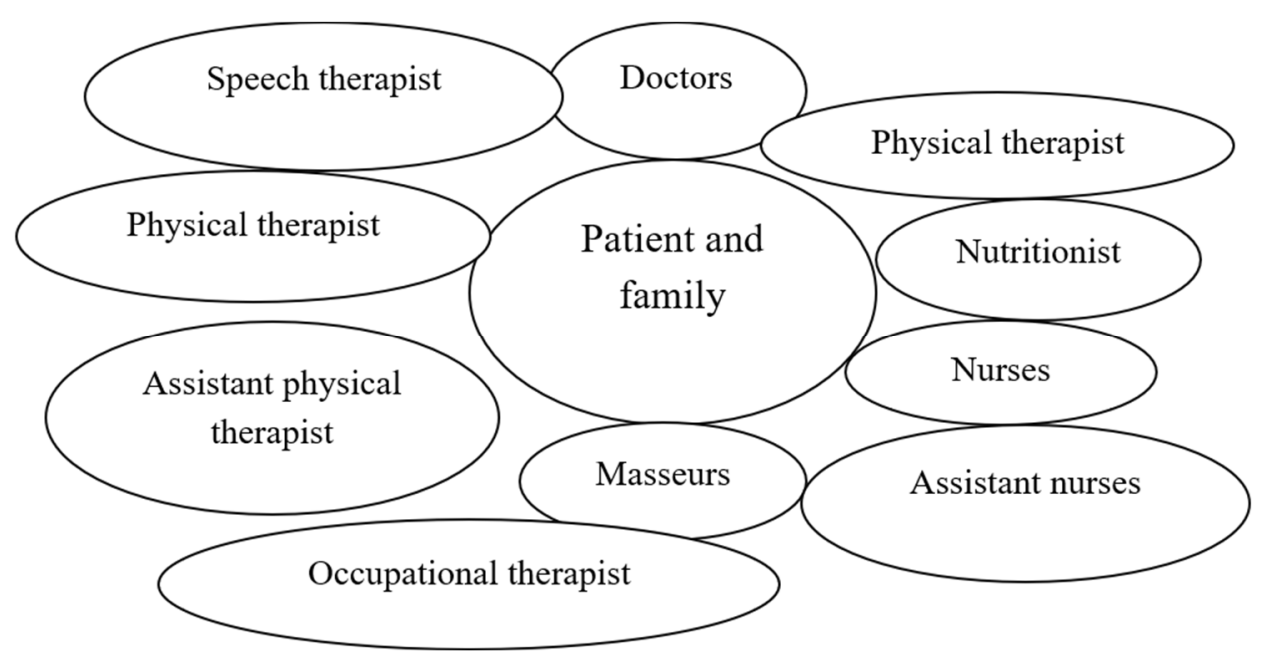

Fig. 1. Multidisciplinary team, impact on recovery and compensation of the patient's lost functions after stroke.

The main specialists at MDK (Figure 1):

- Doctors (neurologists, cardiologist) establish the diagnosis, determine the prognosis, prescribe treatment, give advice, observe the patient in dynamics;

- Speech therapist has the skills to assess and manage swallowing disorders, help in communication, despite the patient's obvious speech disorders (this is important at all stages of treatment) and the introduction of dysphasia;

- Physical therapists assess: the motor capabilities of patients, establish the causes of disorders, apply techniques aimed at restoring balance, coordination, normal motor stereotypes necessary for various everyday activities;

- An occupational therapist, helping patients regain their skills in daily activities and maximizing their involvement in achieving the patient's own life goals, including roles in family and society. Provide advice on optimal changes in the environment, the use of additional comfortable devices for the patient;

- Assistant physical therapist prescribes a motor mode in an immobilized patient to prevent the formation of pressure ulcers, correct positioning of the affected limbs and prevent the formation of pathological postures, 
conduct a rehabilitation examination and prescribe an individual program for early rehabilitation;

- Medical nurses spend with the patient 24 hours a day; carry out the doctor's prescriptions, manipulations: intravenous infusion (droppers), intramuscular injections. Are responsible; skin care, review, assessment and observation of the physical and psychological condition of the patient, taking the necessary measures and timely informing other specialists of the team.

- Massage therapists, four experienced and professional specialists, carry out their work to activate and restore the patient's motor function. Massage in the rehabilitation system occupies one of the key places. It warms up the body, triggers lymph and blood circulation to all organs, activates biologically active points, and normalizes the work of nerve endings, muscles and tendons, which are mostly tense and inactive after a stroke. Through work with the body and limbs at the neural level, they influence the normalization of brain functions, correction of muscles and skeletal system, elimination of imbalance in the body.

- Assistant medical nurses on guard of order and comfort of patients 24 hours a day. The department monitors the hygiene and the complex organization of cleaning.

Experts leading advisory team work:

- Speech therapist;

- Nutritionist;

- Psychotherapist / psychoneurologist.

The Multidisciplinary Approach (TIR) includes:

- Specialized knowledge of each specialist who is part of the MDK;

- Interaction between specialists when examining a patient;

- Joint setting of rehabilitation goals;

- Planned intervention to achieve the goal.

Under the leadership of the head of the department, who is a physician of the PRM (Physical and Rehabilitation Medicine), a close-knit fulfillment of the duties of a multidisciplinary team. Every day at the meeting of the MDK, communication takes place in accordance with medical ethics and moral principles, the legal norms of the patient and his family.

Upon admission to the department on the first day, the patient is examined by a doctor; a physical therapist and an occupational therapist are examined. Each day, an individual patient plan is planned and developed, which is aimed at achieving the set goals. The lesson is carried out 3-4 times a day, depending on the functional state of the patient. The goals achieved can change; each stage of rehabilitation provides great opportunities and needs of patients.

The administration takes care of the rational nutrition of patients. Helping patients with food intake, selecting of the required consistency (puree or soft, saturated with all the necessary vitamins and minerals).

Patients are examined using modern tests and scales, which allow summarizing the examination results, and having a high level of reliability. Modified Ashforth scale of muscle spasticity (from 0 - 5 points), in the proximal and distal regions; Barthel index of daily activity, assessment of the independence of patients in daily life. The modified Rankine scale determines functional independence; the Berg scale determines the translational capabilities, the Tennessee balance and fall risk scale, motor capabilities according to the Rivermead mobility index. The Borg scale determines the intensity of physical activity. The assessment of walking is determined using tests: 6-minute test, 10-meter walk test, etc.

Interventions conducted in the Physical and Rehabilitation Medicine Department:

- Mobility in bed;

- Sitting balance training;

- Using a verticalizer;

- Exercises for the respiratory system;

- Training the patient's body weight transfer;

- Suspension system for walking;

- Cycling training;

- The need for an additional walking aid is assessed individually;

- Using the balance of the platform;

- The patient's skills to overcome architectural barriers within and outside the department;

- Rehabilitation cage for kinesiotherapy, equipped with a suspension system to restore the range of motion, normalize muscle tone, increase muscle strength, improve balance and coordination;

- Kinesiotherapy, the complex is aimed at restoring the motor function of joints and muscles.

- Recovery of movements due to action;

- Mirror therapy helps to restore the activity of the paretic upper and lower extremities through vision and Proprioception;

- Yumeiho therapy - the complex is aimed at correcting the muscles and spine.

- Kinesio taping, against edema, hematomas;

- Exercises to improve vision etc.

No one can say for sure how long the rehabilitation process should take. The program is based on the individual needs of each individual stroke patient, the severity of the disease and the degree after stroke brain damage, concomitant diseases that can interfere with the rehabilitation process. Early rehabilitation contributes to a faster and more complete recovery of lost functions. Don't put off until later what you can restore now.

Purpose of the research: scientifically substantiate the means and principles of physical therapy on the basis of the Kiev City Clinical Hospital № 6, the Department of Physical and Rehabilitation Medicine, the use of which allows achieving optimal results in restoring the patient's motor functions after a stroke. The multidisciplinary team helps patients return to their normal independent daily life. With the help of the ICF, patients continue to plan and arrange their life path, return to work, study, and hobbies.

Materials and research methods. The use of methods of physical therapy in patients after a stroke at the stationary stage. The course of rehabilitation on the basis of KGKB № 6, the Department of Physical and Rehabilitation Medicine, passed: 34 patients in the early recovery period with upper limb plegia, and 26 patients in the late period after a stroke with spasticity of the upper limb. Persons with the age of women from 35 to 83 years old; men aged 37 to 84 were kept for 2 to 3 weeks. The duration of the stroke ranges from 3 weeks to 1 year. The main diseases that led to the development of stroke: cardiovascular diseases, atherosclerosis, diabetes mellitus, constant stress, etc. 
All patients underwent complex physical therapy according to an individual program for every day. The neurological status of the plegia and the motor function of the hand were assessed in points at the beginning of physical therapy and after its completion. For the experiment, the patients were divided into 2 groups (Table 1).

Physical therapy methods in the control group were performed once a day:

- Passive exercises 30 minutes;

- Passive - active exercises for self-fulfillment;

- The technique of temporarily limiting the activity of a healthy limb from 10 to 30 minutes;

- Mirror therapy 30 minutes;

- Kinesio taping with a frequency of 3-4 days.

These methods are auxiliary and cannot exist as an independent and reliable influence, at least $50 \%$ will restore the movement in the end and increase muscle strength.

The main group of patients studied 2 - 3 times a day, for 30-40 minutes. This made it possible to restore the upper limb by 50-60\% in 2 - 3 weeks. By increasing muscle strength, the patients were able to engage the upper limb in daily life.

Statistical processing of the results was carried out, and the effectiveness of the individual program was confirmed by the results of objective research. According to manual muscle testing, a statistical improvement in functional movement in the upper limb was observed. From the given results (Table 1) it can be seen that the developed individual program of physical therapy contributed to the formation of muscle strength in the upper limb.

Comparative table of examination of manual-muscle testing of the upper limb in patients

Table 1 after a stroke from plegia

\begin{tabular}{|c|c|c|c|}
\hline \multicolumn{2}{|c|}{$\begin{array}{l}\text { Main group. } \\
\text { MMT, upper limb, } 17 \text { patients from plegia }\end{array}$} & \multicolumn{2}{|c|}{$\begin{array}{l}\text { Control group. } \\
\text { MMT, upper limb, } 17 \text { patients from plegia }\end{array}$} \\
\hline \multicolumn{2}{|c|}{ before and after } & \multicolumn{2}{|c|}{ before and after } \\
\hline \multicolumn{4}{|c|}{ Scapula muscles } \\
\hline 0 & 3 & 0 & 1 \\
\hline \multicolumn{4}{|c|}{ Shoulder joint } \\
\hline 0 & 3 & 0 & 1 \\
\hline \multicolumn{4}{|c|}{ Elbow joint } \\
\hline 0 & 3 & 0 & 0 \\
\hline \multicolumn{4}{|c|}{ Wrist } \\
\hline 0 & 3 & 0 & 0 \\
\hline \multicolumn{4}{|c|}{ Finger joints } \\
\hline 0 & 3 & 0 & 0 \\
\hline
\end{tabular}

Physical therapy methods for the main group were carried out 2 - 3 times a day for 30 - 40 minutes:

- Point effect on muscles;

- Correctional exercises;

- Post-isometric relaxation;

- Exercises for fine and gross hand motor skills;

- Manual muscle stimulation techniques.

The use of methods of point action on the plexus muscles in combination with post-isometric relaxation. Point action made it possible to activate and awaken muscles, restore neural connection. Post-isometric relaxation increased resistance and strengthened muscle strength in the arm. Exercises for fine motor skills in the hand allow you to restore grasping movements. Even if the MMT has 0 points, there is no movement at all. The combination of these methods allows patients, after undergoing a rehabilitation program, to use cutlery, button up, comb, and more.

Physical therapy is a complex of methods that help restore the function of movements for performing the necessary actions in everyday life. Training of all muscles occurs through the implementation of loading, the movements vary in degree of complexity. The more muscles the patient engages in action, the faster they recover the lost motor functions.

The neurological status of spasticity and motor function of the hand were assessed in points at the beginning of physical therapy and after its completion. For the experiment, the patients were divided into 2 groups (Table 2).

To restore spastic muscles in the control group, methods were used once a day for 30-40 minutes from 2 to 3 weeks:

- Treatment by position;

- Orthotics for the upper limb;

- Passive active exercise 30 minutes

- Kinesio taping duration of use 3 - 4 days;

- Exercises with stretching of spastic muscles 15 20 min.;

- Mirror therapy $30 \mathrm{~min}$.

The obtained statistical results in the control group did not bring positive dynamics of new movements of the functions of spastic muscles. The effectiveness of therapeutic measures is not sufficiently high, these methods, over time, can provoke an increase in spasticity. This made it necessarily to develop an individual rehabilitation plan that would reduce muscle spasticity, painful sensations, increase the range of motion and enable the patient to further involve the limb in everyday activities. So, according to the data of statistical processing of the results before and after the methods of physical therapy, the complex program contributed to the improvement of motor function, more than a standard technique. 
Table 2

Dynamics of research indicators in the main and control groups of patients with upper limb spasticity after using individual rehabilitation programs

\begin{tabular}{|c|c|c|c|}
\hline \multicolumn{2}{|c|}{ Main group of 13 patients } & \multicolumn{2}{|c|}{ Control group of 13 patients } \\
\hline Initial examination & After rehabilitation & Initial examination & After rehabilitation \\
\hline \multicolumn{4}{|c|}{ Shoulder pain, points } \\
\hline From $4-7 \mathrm{p}$. & From $2-3 \mathrm{p}$ & From $4-7 \mathrm{p}$. & From 4-6p. \\
\hline \multicolumn{4}{|c|}{ Degree of spasticity } \\
\hline $3-4 \mathrm{p}$. & $1-2 \mathrm{p}$. & $3-4 \mathrm{p}$ & $3-4 \mathrm{p}$ \\
\hline \multicolumn{4}{|c|}{ Amplitude of active shoulder flexion, degrees } \\
\hline $38,05-1,18$ & $55,07-2,25$ & $3,66-0,34$ & $4,35-027$ \\
\hline \multicolumn{4}{|c|}{ Amplitude of active shoulder abduction, degrees } \\
\hline $35,08-2,24$ & $45,08-1,63$ & $40,22-2,48$ & $42,00-1,02$ \\
\hline \multicolumn{4}{|c|}{ Amplitude of active flexion of the forearm, degrees } \\
\hline $54,08-5,19$ & $80,08-4,20$ & $52,11-2,60$ & $55,00-3,05$ \\
\hline \multicolumn{4}{|c|}{ Active degree forearm extension } \\
\hline $66,69-2,86$ & $85,43-5,29$ & $62,43-1,39$ & $65,35-3,36$ \\
\hline
\end{tabular}

Classes in the main group were conducted 2 - 3 times a day, 40 - 60 minutes each. The patients used the method of muscle correction in combination with post-isometric relaxation. The proposal consisted in influencing the drive and flexors of the muscles with a point effect, reducing the tone of the spastic muscles, combining with passive stretching exercises.

In this technique, a beneficial effect on reducing muscle tone is associated with deep point penetration into the spasmodic muscle and passive stretching exercises along all axes of the upper limb has a profound effect on the restoration and improvement of the functional activity of the limb. When active movements appear in the limb, we add post-isometric relaxation to the abductor and extensor muscles, strengthening and bringing the muscles into a state of symmetry.

In post-stroke patients, upper limb motor function is important for functional capacity and self-care. The main function of the upper limb is the ability to grip and hold objects, fine movements of the fingers. These functions are performed by the muscles of the forearm and hand. The pronounced spasticity of these muscles completely excludes the patient's upper limb from everyday life. So, one of the first tasks in the rehabilitation of a patient with muscle spasticity is to restore the function of the shoulder, forearm and hand. For this purpose, muscle correction, passive stretching exercises and post-isometric relaxation are used. The development of effective methods of physical therapy for the recovery and rehabilitation of patients after stroke with spasticity of the upper limb is an important component of people's independence in their usual individual everyday life needs.

Results of the study. The unpredictability of the pathogenesis of patients after stroke, a variety of cognitive disorders, defects of the musculoskeletal system, various residual effects, etc. The ICF scheme in physical therapy involves close cooperation with the patient and family to determine specific goals and achieve, taking into account the limitation of participation [5].

For example, consider one of our patients, with the permission of relatives and the person himself. Name changed for personal legal confidentiality. Patient T.M. (80 years old) was admitted to the department on 10/20/2020.

Clinical use of ICF (Table 3). Diagnosis upon admission to the Department of Physical and Rehabilitation Medicine: Ischemic stroke in the right carotid basin, leftsided hemiparesis. At the time of admission, the patient was as dependent on the medical staff as possible.

The short-term goals of the occupational therapist have been agreed with the patient and his family:

1) After 1 week $(10 / 20 / 2020-10 / 27 / 2020)$ T.M. independently sitting on a chair near the washbasin, carry out morning and evening hygiene (washing hands, washing, brushing teeth, and combing hair).

2) After 2 weeks T.M. take food on their own, holding a fork or spoon in their right hand, support the plate with the left, wash the dishes and put them in place at the end.

The short-term goals of the physical therapist have been agreed with the patient and his family:

1) After 2 weeks T.M. under supervision, will walk 60 meters without aids.

2) Goal in start format: After 2 weeks T.M. under supervision, will reach the toilet without aids, fulfill their physiological needs, carry out hygiene procedures. 


\section{Initial examination of the patient by ICF \\ Health status \\ Ischemic stroke in the right carotid system}

Previous post: Ischemic heart disease, atherosclerosis, GB III, cardiosclerosis

The structure and functions of the body

Left-sided hemiparesis of the upper and lower extremities; Cognitive impairment - Neglect syndrome;

Psychological trauma

Does not control physiological needs,

\section{Activity}

After a stroke, she is maximally dependent on outside help

Medium self help;

Coordination and balance are disturbed; Activity limitation:

Impossibility of self-service: dressing, Personal hygiene, Eating, Cooking

Table 3

\section{Environmental factors}

10 steps at the entrance to the staircase;

The niece and grandson live in a different area.

Psychological and emotional support, they are encouraged every day, they call.

There is a friend who calls 3 times a week, on good terms.

\section{Ischemic heart disease, atherosclerosis, GB III, car- diosclerosis.}

Active pensioner, woman, 80 years old., Ukrainian, higher education, previously held the position of leader.
Initial examination of the patient by the therapist from the moment of admission to the final rehabilitation result. Introduction to occupational therapy, every morning according to the possibilities and individual needs of the patient was carried out (Table 4): and shoes);
- Personal hygiene (washing hands, washing, brushing teeth, combing hair);

- Food intake;

- Cooking;

- Restoring writing, improving fine motor skills

- Classes with cognitive impairments;

- Exercises to improve vision;

- Analysis of mobile phone (take a call, call).

Table 4

Examination by occupational therapist

\begin{tabular}{|l|c|c|}
\hline \multicolumn{1}{|c|}{ Examination } & $\begin{array}{c}\text { Initial examination } \\
10 / 20 / 2020\end{array}$ & $\begin{array}{c}\text { Final examination } \\
11 / 27 / 2020\end{array}$ \\
\hline Bartel's daily life activity index is $100 \mathrm{bp}$. & $10 \mathrm{p}$. & $22 \mathrm{p}$. \\
\hline MMSE $-25 / 30 \mathrm{p}$. & $9 \mathrm{p}$. & $16 \mathrm{p}$. \\
\hline MoCA $-26 / 30 \mathrm{p}$. & $11 \mathrm{p}$. & 6 power \\
\hline Cross out test, norm 20 & Right - 16, left -9 & 5 power \\
\hline The degree of shoulder pain is 7 tbsp. & 4 power & 4 power \\
\hline The degree of hand restoration is 7 tbsp. & 2 power & 0 p. \\
\hline Brush renewal stage 7 tbsp. & 2 power & 0 p. \\
\hline Ashworth from 0 - $5 \mathrm{p}$ & & \\
\hline
\end{tabular}

Initial examination by a physical therapist from the moment of admission to the end of the rehabilitation program. The physical therapist conducted classes 2 - 3 times a day for 30 - 40 minutes (Table 5):

- Mobility training in bed and outside;

- Verticalization;

- Shifting body weight to restore stroke;

- Strength training to strengthen weak muscles;

- Exercises for balance and coordination;

- Respiratory techniques;
- Kinesiotherapy performing complex practices to restore functional movement in the joints and strengthen muscles;

- Techniques of gentle manual therapy (including mobilization / manipulation), post-isometric relaxation strengthens the support function of the legs, strengthens muscle strength and corrects the patient's posture;

- Yumeiho therapy helps to restore the motor function of weak and plegial muscles. 
Physical therapist examination

\begin{tabular}{|l|c|c|}
\hline \multicolumn{1}{|c|}{ Examination } & Initial examination $10 / 20 / 2020$ & Final examination $11 / 27 / 2020$ \\
\hline Berg's scale - 56 p. & $2 \mathrm{p}$. & $35 \mathrm{p}$. \\
\hline Rivermead RMI Mobility Index - 15 points. & $0 \mathrm{p}$. & $7 \mathrm{p}$. \\
\hline The modified Rankine scale is from 0 -5 to. & $5 \mathrm{p}$. & $3 \mathrm{p}$. \\
\hline Leg recovery & 3 power & 5 power \\
\hline Recovery rate of the foot & 3 power & 5 power \\
\hline Pain degree & 5 power & 7 power \\
\hline Modified Ashworth scale - mAS 0-5 s. & $0 \mathrm{p}$. & $0 \mathrm{p}$. \\
\hline Postural control 7 degree & $2 \mathrm{p}$. & $5 \mathrm{p}$. \\
\hline Get up and walk test & unable to do & 3 minute 27 sek. \\
\hline
\end{tabular}

The massage specialist performed therapeutic massage in order to reduce painful sensations in the shoulder, swelling in the hand, prevent subluxation and strengthen muscle strength, increase the range of motion of the upper and lower extremities.

The use of the ICF allows you to analyze the existing disabilities; change the degree and build a rehabilitation program; plan and develop a sequence of rehabilitation measures; to characterize the effectiveness of rehabilitation [6].

Discussion of the results: as a result of the conducted ergo therapeutic exercises in T.M. improved selfservice skills in daily life. At the time of discharge, the patient independently performs morning and evening hygiene procedures; takes food; controls his physiological needs, uses the bedside toilet if necessary. With minimal help, she gets dressed.

At the time of discharge, TM had improved coordination and balance in an upright position. The patient may roll over from side to side; sit down from a lying position; walk 60 meters under supervision without aids. With minimal assistance, he can climb to the second floor.

Analysis of special literature devoted to the problem of limitation of active motor functions after a stroke. The use of splints on the upper limb to reduce spasticity was not significantly affected. The use of acupuncture should not be considered a treatment for spasticity in daily practice, except as part of research [8].

It is not recommended for stroke patients to stretch regularly to reduce spasticity [2]. This can provoke a reflex increase in muscle tone.

The use of electromyography with biofeedback, no significant result was obtained $[4,15]$.

The use of the ICF allows the multidisciplinary team to listen to the needs and wishes of the patient. Of $100 \%$ of patients, $99.8 \%$ have a request to restore the motor function of the upper or lower limb for attraction or use in everyday activities. An integrated approach and methods of physical therapy have a positive effect on the functional state of the muscles.

Conclusion. Physical therapy for patients after stroke should take into account the principles and necessary individual needs of the patient throughout the entire rehabilitation process. Given the goals set consistent with the patient and his family. Using the International Classification of Functioning for Stroke patients to improve activity and participation in life; improve the structure and functions of the body; to reduce the limitation in life.

The relevance of the topic physical therapy of patients after stroke is constantly being researched. To navigate current trends, you need to follow international guidelines and standards that are constantly updated.

Prospects for further research are to determine the effectiveness of using the developed individual program of physical therapy and methods for restoring motor functions in patients after stroke with rescue of the upper limb in the late period.

\section{References:}

1. Clinical Guidelines for Stroke Management 2017. Available from: https://informme.org.au/ en/Guidelines/Clinical-Guidelines-for-Stroke-Management2017.

2. Harvey LA, Katalinic OM, Herbert RD, Moseley AM, Lannin NA, Schurr K : Stretch for the treatment and prevention of contractures. The Cochrane database of systematic reviews 2017 Jan 9;1(1).

3. Hertsyk A. SMART goal setting in physical therapy. Phys.education, sports and health culture in modern.total:Sat.scientific textbook 2016; 2(34):57-116.

4. Holdblat JV. Osnovy reabilitasii nevrologicheskih bolnuh: monografiya - Sankt - Peterburg: SpesLit. 2017.

5. Imas Y, Lazarieva O. Pre-conditions and modern development of specialities in physical therapy and ergotherapy in Ukraine. Fizvykhovannia, sport i kultura zdorovia u suchasnomy suspilstvi. 2017; 2(38):10-15.

6. International Classification of Functioning, Disability and Health (ICF) https://www.who.int/ classifications/international-classification-offunctioning-disability-and-health

7. Khudezkuy IY, Khomenko YS, Antonova-Rafi JV. Osobluvosti fizychnoyi reabilitatsiya ljudey pokhylogo viku iz nevrolohichnymy zakhvorjuvannyamy. Molodyy vchenyy. 2018; 10(1):155-7.

8. Lim SM, Yoo J, Lee E, Kim HJ, Shin S, Han G, Ahn HS: Acupuncture for spasticity after stroke: a systematic review and meta-analysis of randomized controlled trials. Evidence-based complementary and alternative medicine: eCAM 2015; Apr 5.

9. Mountain A. et al. Canadian Stroke Best Practice Recommendations: Rehabilitation, Recovery, and Community Participation following Stroke. Part Two: Transitions and Community Participation Following 
Stroke. International Journal of Stroke. 2020. Oct;15(7):789-806.

10. Nakaz Ministerstva ohorony zdorovya Ukrainy 17.04.2014 № 275 Unifikovanuy klinichnuy protocol ekstrenoyi, pervunnoyi, vtorunnoyi (spesializovanoyi), tretynoyi (vysokospesializovanoyi) meduchnoyi ta meduchnoyi reabilitasiyi. Hemorahichnuyi insylt (vnutrishnomozkova hematoma, anevruzmalnuyi sybarakhnoidalnuyi krovovylyv).

11. Norrving B, Barrick J, Davalos A, Dichgans M, Cordonnier C, Guekht A, Caso V. Action Plan for Stroke in Europe. 2018-2030. European Stroke Journal. 2019; 3(4):4-32

12. Powers WJ, et al. Guidelines for the Early Management of Patients With Acute Ischemic Stroke: A Guideline for Healthcare Professionals From the American Heart Association / American Stroke Association. Stroke. 2018; 49(3):46-99. doi: $10.1161 /$ str.0000000000000158

13. Teasell R, et al. Canadian Stroke Best Practice Recommendations: Rehabilitation, Recovery, and Community Participation following Stroke. Part One: Rehabilitation and Recovery Following Stroke; 6th Edition Update 2019. International Journal of Stroke. 2020.

14. Spezializovanyy medychnyy portal - https://healthua.com/article/60091-nsult-yak-odin-z-najblshih-medikosotcalnih-viklikv-sogodennya

15. VA/DoD Clinical practice guideline for the management of stroke rehabilitation.2019.Availablefrom:https:/www.healthquality.va.gov/guidelines/Rehab/stroke/VADoDStrokeRehabCPGFinal8292019.pdf

16. WHO methods and data sources for global causes of death 2000-2016. Global Health Estimates Technical Paper WHO/HIS/IER/GHE/2018.3. Geneva: World Health Organization; 2018. Available from: http:/www.who.int/ healthinfo/global_burden_disease/GlobalCOD_method_2000_2016.pdf].

\section{УДК 615.825:616.831 \\ ФІЗИЧНА ТЕРАПІЯ ПАЦІЕНТІВ ПІСЛЯ ІНСУЛЬТУ}

\section{А.В. Гомола, Є.В. Прокопович, Ю.В. Антонова-Рафі}

Національний технічний університет Украӥни «КПІ» імені Ігоря Сікорського, кафедра біомедичної інженерії, м. Київ, Україна, ORCID ID: 0000-0001-7431-1889,

ORCID ID: 0000-0002-7107-5021, ORCID ID: 0000-0002-9518-4492, e-mail:alhzgv@gmail.com

Резюме. За узагальненими відомостями про поширення та ускладнення пацієнтів після інсульту в Україні та у світі, в основі інвалідизації відмічені рухові та когнітивні порушення. Багато версій щодо фізичної терапії пацієнтів після інсульту у гострому та ранньому періоді. Українська асоціація боротьби з інсультом створила протоколи реабілітаційної допомоги. Досягнули успіху в реабілітації пацієнтів у гострому періоді. Виникають труднощі у пізньому періоді, а саме - функціонально рухових порушень. Це негативно впливає на соціально-побутову активність та звичну діяльність пацієнтів. Наслідок - м'язові порушення, такі як плегія, що супроводжується больовим синдромом, втратою рівноваги та координації. Наростаюча спастичність, яка формує контрактури, виникають больові відчуття, обмеження у побутових діях. Фізичний терапевт має володіти, знати і використовувати методи та засоби фізичної терапії. Використання МКФ впливає на хід роботи МДК, направлений на прямий та конкретний реабілітаційний процес для якісного та комплексного відновлення втрачених рухових функцій пацієнта.

Мета дослідження: дослідили динаміку функціонально-рухового стану пацієнтів після проходження комплексної фізичної терапії. Обгрунтували ефективність методів для відновлення функціональнорухових можливостей на стаціонарному етапі.

Висновки. Запропонований перелік реалізованих методів, наведені принципи фізичної терапії пацієнтів після інсульту на базі КМКЛ №6, відділення фізичної та реабілітаційної медицини. МДК не ділить життя на «до» і «після» інсульту, на основі доказової медицини, комплексним та індивідуальним підходом активує до самостійного життя, допомагає відновити втрачені функції, знаходить вихід там, де інші відмовляються.

Ключові слова: інсульт, реабілітація, фізична терапія, Мультидисциплінарна команда, Міжнародна класифікація функціонування.

\section{УДК 615.825: 616.831 \\ ФИЗИЧЕСКАЯ ТЕРАПИЯ ПАЦИЕНТОВ ПОСЛЕ ИНСУЛЬТА}

А.В. Гомола, Е.В. Прокопович, Ю.В. Антонова-Рафи

Национальный технический университет Украины «КПИ» имени Игоря Сикорского, кафедра

биомедицинской инженерии,

2. Киев, Украина,

ORCID ID: 0000-0001-7431-1889,

ORCID ID: 0000-0002-7107-5021,

ORCID ID: 0000-0002-9518-4492,

e-mail:alhzgv@gmail.com

Резюме. Соответственно обобщенным сведениям о распространении и осложнении пациентов после инсульта в Украине и в мире, в основе инвалидизации отмечены двигательные, когнитивные нарушения. Много версий по физической терапии пациентов после инсульта в остром и раннем периоде. Украинская ассоциация борьбы с инсультом создала протоколы реабилитационной помощи. Достигли успеха в реабилитации пациентов в остром периоде. Возникают трудности в позднем периоде, а именно - функционально двигательных нарушений, что негативно влияет на социально-бытовую активность и привычную деятельность пациентов. Мышечные нарушения, такие как плегия, сопровождаются болевым 
синдромом, потерей равновесия, координации. Нарастающая спастичность формирует контрактуры, возникают болевые ощущения, ограничения в быту. Физический терапевт должен обладать и использовать методы и средства физической терапии. МКФ влияет на ход работы МДК, направленный на прямой и конкретный реабилитационный процесс для качественного и комплексного восстановления утраченных двигательных функций пациента.

Цель исследования: исследовали динамику функционально-двигательного состояния пациентов после прохождения комплексной физической терапии. Обосновали эффективность методов для восстановления функционально-двигательных возможностей на стационарном этапе.
Выводы. Предложен перечень реализованных методов, приведены принципы физической терапии пациентов после инсульта на базе КГКБ №6, отделение физической и реабилитационной медицины. МДК не разделяет жизнь на «до» и «после» инсульта, на основе доказательной медицины, комплексным и индивидуальным подходом активирует к самостоятельной жизни, помогает восстановить утраченные функции, находит выход, где другие отказываются.

Ключевые слова: инсульт, реабилитация, физическая терапия, Мультидисциплинарная команда, Международная классификация функционирования.

Стаття надійшла в редакцію 13.12 .2020 р. 